\title{
Ecophysiological and biochemical variation of the surf zone diatom asterionellopsis glacialis sensu lato from Santa Catarina, Southern Brazil*
}

\author{
Leonardo Rubi Rörig ${ }^{1 * *}$, Milena Camargo Honorato ${ }^{1}$, Ana Gabriela Itokazu ${ }^{1}$, Carolina Ximenes de \\ Macedo ${ }^{2}$, Francisco Deschamps ${ }^{3}$, João Vitor Heberle Lins ${ }^{1}$, Marcelo Maraschin ${ }^{1}$, Fernanda \\ Ramlov $^{1}$, Pablo Diego Gressler ${ }^{1}$, Jurandir Pereira Filho ${ }^{4}$
}

${ }^{1}$ Universidade de Santa Catarina - Laboratory of Phycology

(Campus Trindade - Florianópolis - Santa Catarina - 88040-900 - Brazil)

${ }^{2}$ Boticário Foundation

${ }^{3}$ Empresa de Pesquisa Agropecuária e Extensão Rural - EPAGRI

Rodovia Admar Gonzaga, 1347 - Itacorubi, Cx Postal 502 - Florianópolis - SC - 88034901 - Brazil)

${ }^{4}$ Universidade do Vale do Itajaí - Laboratory of Chemical Oceanography

( Rua Uruguai, 458 - Centro - Itajaí - SC - 88302202 - Brazil)

**Corresponding author: leororig@gmail.com

\section{Abstract}

Patches formed by dense accumulations of diatoms in the surf zone (surf diatoms) are common on sandy beaches with intermediate to dissipative morphodynamic states. Their appearances are correlated with environmental factors such as the passage of cold fronts when onshore winds increase beach hydrodynamics, resuspending epibenthic stocks and accumulating them through the inner surf zone. In Santa Catarina state, Southern Brazil, two beaches are known to have frequent occurrence of accumulations of the surf diatom Asterionellopsis glacialis sensu lato: Rincão Beach (28 $\left.50^{\prime} \mathrm{S}\right)$ and Navegantes Beach $\left(26^{\circ} 52^{\prime} \mathrm{S}\right)$. The high biomass of this alga and its central importance in the trophic structure of the coastal ecosystems suggest studies about its potential applications. In the present study, strains of A. glacialis were isolated, cultured under different conditions and evaluated for ecophysiological aspects: growth rate under different conditions, potential biological activities of exudates, biomass and lipid content, and fatty acid profile. A. glacialis cells in culture showed deformation, which were ameliorated by using agitation and silicon and phosphorus enriched culture media. Exudates of the strains
RESUMo

Manchas formadas por densas acumulações de diatomáceas na zona de arrebentação ("diatomáceas de surf") são comuns em praias arenosas com estados morfodinâmicos dissipativos ou intermediários. Seu aparecimento está correlacionado com fatores ambientais, como a passagem de frentes frias, quando ventos em direção a praia promovem maior hidrodinâmica, gerando ressuspensão de estoques bênticos das diatomáceas, acumulando-as na zona de arrebentação interna. No estado de Santa Catarina, sul do Brasil, duas praias são conhecidas por terem frequente ocorrência de acumulações da diatomácea de zona de arrebentação Asterionellopsis glacialis lato sensu: Praia do Rincão ( $28^{\circ} 50$ 'S) e Praia de Navegantes $\left(26^{\circ} 52^{\prime} \mathrm{S}\right)$. A alta biomassa desta alga e sua importância central na estrutura trófica dos ecossistemas costeiros sugerem estudos sobre suas potenciais aplicações. No presente estudo, cepas de A. glacialis foram isoladas, cultivadas sob diferentes condições e avaliadas quanto a aspectos ecofisiológicos (taxas de crescimento, atividades biológicas de exsudatos e biomassa) e bioquímicos (conteúdo lipídico e perfil de ácidos graxos). As células de A. glacialis em cultura mostraram deformações, as quais

Received: December 9, 2015

Approved: July 6, 2017

* Paper presented in the International Sandy Beach Symposium, 7. 2015, Ilhabela, São Paulo, Brazil . 
showed no allelopathic effects, although previous studies have indicated activity. Lipid content showed variation depending on the strain and culture media. Values ranged from $9 \%$ to $13.6 \%$ by dry weight. In all strains saturated fatty acids and polyunsaturated fatty acids were identified. Some hypotheses were proposed to explain the variation of the lipid contents, fatty acid profiles and physiological features between strains of the same species. We believe that the fatty acids profile of this primary producer has important consequences in the sandy beach ecology.

Descriptors: Phytoplankton, Diatoms, Fatty Acids, Allelopathy, Antimicrobial Activity.

\section{INTRODUCTION}

The occurrence of dense accumulations of diatoms in the surf zone is a typical feature of many exposed, intermediate to dissipative sandy beaches, (BROWN; MCLACHLAN, 1990). These accumulations appear as flocculent brown patches on the water surface, attached to the foam generated by breaking waves (MACKAS; LEWIN, 1972). Its formation is governed by resuspension processes of benthic stocks from beyond the surf zone as a result of wave energy increases generated by storms, coupled with physiological adaptations for floating and sinking of the species involved (TALBOT; BATE, 1988; RÖRIG et al., 1997; ODEBRECHT et al., 2010). The accumulations or patches are usually monospecific or occasionally with two or more co-dominant species (VAN HEURCK, 1896; THAYER, 1935, RAPSON, 1954; MCLACHLAN; LEWIN, 1981 RÖRIG; GARCIA, 2003). Around the world, at least six species not necessarily taxonomically close, compose the phenomena: Aulacodiscus kittonii Arnott, Aulacodiscus africanus Cottam, Anaulus australis Drebes at Schulz, Asterionellopsis glacialis (Castracane) Round, Asterionella socialis Lewin et Norris and Attheya armatus (T. West) Crawford (CAMPBELL, 1996). Recently, molecular studies showed that A. glacialis actually comprises a group of 5 cryptic species, showing a more complex situation than previously conceived (KACZMARSKA et al., 2014).

Several studies have indicated the central trophic importance of the surf zone diatoms to different components foram melhoradas, usando agitação e meios de cultura ricos em silício e fósforo. $\mathrm{O}$ exsudato das cepas não mostrou efeito alelopático nem antimicrobiano, embora estudos anteriores tenham indicado essa atividade. O conteúdo lipídico apresentou variação dependendo da cepa e do meio de cultura utilizado. Os valores variaram entre $9 \%$ e 13,6\%, em massa seca. Em todas as cepas foram identificados ácidos graxos saturados e poli-insaturados. Algumas hipóteses foram propostas para explicar a variação considerável nos níveis de lipídeos, nos perfis de ácidos graxos e as características ecofisiológicas das cepas. Além disso, sugerimos que o conteúdo e a composição de ácidos graxos pode ter consequências importantes na ecologia das praias arenosas onde A. glacialis ocorre como o principal produtor primário.

Descritores: Fitoplâncton, Diatomáceas, Ácidos Graxos, Alelopatia, Atividade Antimicrobiana.

of beach ecosystem including supralitoral and dunes (e.g. BROWN, 1964; GIANUCA, 1983; LEWIN; SCHAEFER, 1983; MCLACHLAN; ROMER, 1990; BROWN; MCLACHLAN, 1990, LERCARI et al., 2010; ODEBRECHT et al., 2014). Among the biomolecules produced and made available trophically by diatoms, fatty acids are probably the more relevant. These molecules provide not only energy, but in the case of polyunsaturated fatty acids (PUFA) are also critical for maintaining high growth, survival and reproductive rates; improve food conversion efficiency; and play key regulatory roles in the physiology animal cell membranes, being the precursors of many animals hormones (BRETT; MÜLLERNAVARRA, 1997). Considering the dominance of surf diatoms in environments where the accumulation phenomena occurs, it is very likely that they are the main source of essential fatty acids for beach fauna.

Moreover, ABREU et al., (2003) found that the appearance of $A$. glacialis patches promotes, at first, a reduction in the abundance of bacteria and subsequently, when the patches decay, bacterial biomass increases, indicating consumption of the dissolved organic matter provided by the microalgae. This fact indicates a possible bacteriostatic effect coming from microalgae exsudates. In this case, internal or environmental factors must be controlling the production of metabolites.

Several abiotic and biotic factors can cause changes in microalgae metabolism. For example, the availability of light, nutrients and $\mathrm{CO}_{2}$ can cause changes in the 
lipid content and composition (SPOLAORE et al., 2006). Under nutrient limitation growth rates decrease and cell metabolism is redirected to triacilglicerides (TAG) accumulation as energy reserves, rather than the synthesis of phospholipids and proteins, as usually occurs in optimal conditions (BEHRENS; KYLE, 1996). The TAG are composed mostly of palmitic and palmitoleic acid; phospholipids are mainly composed of polyunsaturated fatty acids (GRIMA et al.,1999).

In some cases, the presence of grazers and their metabolites in water may induce microalgae morphological changes or toxin production as defence strategies to avoid grazing (POHNERT; et al., 2007). This morphological and metabolomic plasticity can be phenotypic or genotypic, characterizing ecotypes and, eventually, the existence of taxonomic subcategories.

In the case of $A$. glacialis sensu lato, both situations can occur, since its worldwide distribution and the recent discovery of different cryptic species may reflect genetic and ecological differences, which can be related to production or not production of different metabolites. A few studies have been conducted on the chemical profile and biological activity of $A$. glacialis molecules. AUBERT et al., (1970) found that extracts of this species have antimitotic properties. RIQUELME; ISHIDA (1988) reported antibiotic activity against Vibrio spp., but stimulatory activity for Pseudomonas spp. SHIMIZU (1993) isolated the possible molecule responsible for the antibiotic activity, which was called Asterionellin. This molecule is characterized by the presence of the unusual group diazotate. More recently, WICHARD et al. (2005) detected the presence of poliunsaturated aldehydes (PUA) in A. glacialis, a group of molecules that seems to exert negative influence on the reproductive success of copepods and other invertebrates.
Thus, knowing the lipid content and fatty acid profile of these diatoms in different conditions or different strains is a key factor to understand the ecology of the ecosystems where they occur as well as to eventually propose biotechnological applications. Similarly, detection of biological activities (antibiotic, allelopathic) of extracts from different treatments or samples from different locations can reveal defense mechanisms, which may be induced by environmental stress or by expression of strain's specific genes.

Considering these aspects, the present study is based in the following questions:

Do the exsudates and extracts from biomass obtained in the field and laboratory cultures have biological activities?

Does the biomass has nutritional properties that qualify the species as the central primary producer in the beaches where it occurs?

Is it worthwhile to produce biomass by cultivation to obtain biomolecules with a nutritional or biotechnological importance?

To verify these postulations, conventional experimental approaches were adopted, involving the isolation, cultivation and analysis of biomass and exudates produced by two A. glacialis sensu lato strains, attempting to connect ecology and biotechnology.

\section{MATERIAL AND METHODS}

This study follows two approaches, one ecophysiological and one biochemical. In the ecophysiological approach two strains of $A$. glacialis s.l. were isolated evaluated in laboratory assays. The biochemical part involved the analysis of biomass collected in the field and produced in the laboratory in terms of biological activities and biochemical composition (lipids/fatty acids). Figure 1 shows a general scheme of such approaches and the main procedures. 

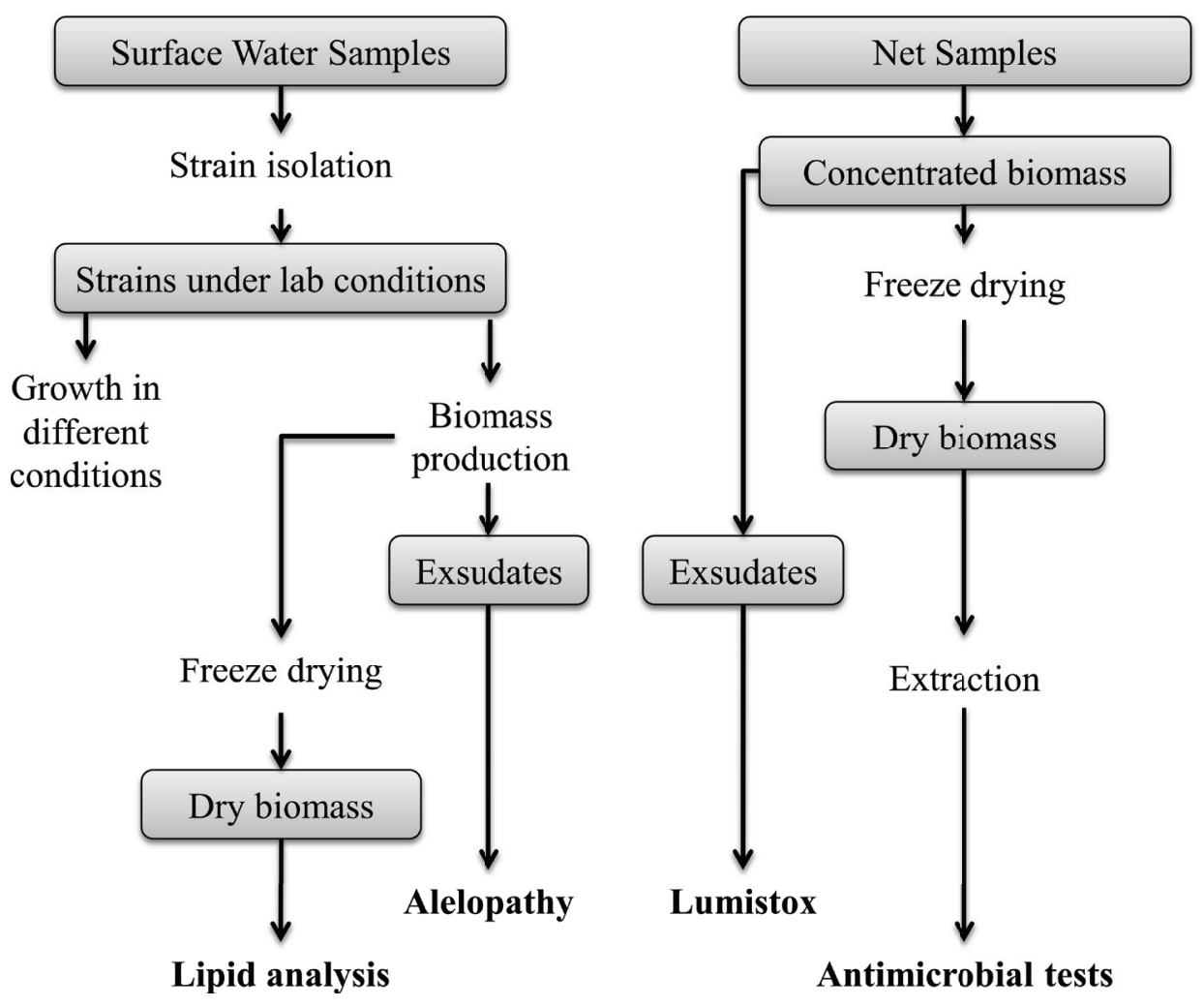

Figure 1. General scheme of methodological procedures used in samples obtained from A. glacialis sensu lato accumulations or patches.

\section{BIOLOGICAL MATERIAL}

A. glacialis samples were obtained from blooms/ patches in the inner surf zone. During each sampling, the biomass was collected using a plankton net (mesh size $20 \mu \mathrm{m}$ ), with successive hauls for material concentration. The biomass was then transferred to sample bottles and kept in a cooler with ice and transported to laboratory for posterior biochemical and biological activity evaluations.

Two strains of different origins were isolated and cultivated for the ecophysiological and biochemical evaluations: (a) Navegantes strain (NAV), isolated from Navegantes beach sample (Navegantes - SC - Brazil -

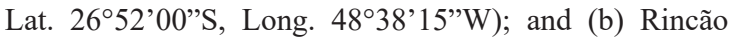
strain (RIN), isolated from Rincão beach sample (Içara

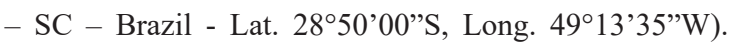
For the isolation process, surface water samples were collected with a bucket and maintained at low temperature in the dark until processing in the laboratory. Under inverted microscope, diatom cells or chains were isolated through the capillary isolation technique (ANDERSEN, 2006). Standard cultivation conditions were: salinity 30, F/2 culture medium according to ANDERSEN (2006), irradiance of $50 \mu \mathrm{Mol} \cdot \mathrm{m}^{-2} \cdot \mathrm{s}^{-1}$ (58W daylight fluorescent lamps), photoperiod of 12 hours and temperature of $22^{\circ}$ $\pm 2^{\circ} \mathrm{C}$. Cultures were maintained in $250 \mathrm{~mL}$ Erlenmeyer flasks with $100 \mathrm{~mL}$ of culture medium. Once the isolates presented visible growth, suggesting physiological acclimation to laboratory conditions, weekly subcultures were performed for maintenance.

Isolations and experiments with NAV and RIN strains were performed at different times (NAV in 2009 and RIN 2013). As a result, some tests were made only with RIN strain due to logistical issues.

\section{STRAINS GROWTH RATE}

The growth of strain RIN was tested in two culture media, F/2 medium according to ANDERSEN (2006) and IMR medium according to EPPLEY et al., (1967). The 
growth of strain NAV was only tested with F/2 medium. These two media are similar in composition but different in relative concentration of macronutrients, where $\mathrm{Si}: \mathrm{N}: \mathrm{P}$ ratio for $F / 2$ is $4.5: 11: 1$ and for IMR is $15: 5: 1$.

Two growth experiments were conducted: (a) with culture medium and agitation variation; and (b) with salinity variation. In the first case, the experiment operated with four replicates for each strain, totaling 8 flasks with F/2 culture medium and 8 flasks with IMR culture medium. Four flasks of each culture medium were placed in shaker and four flasks placed in static bench. In the second case, both strains were grown only in F/2 culture media, but in 6 different salinities: 15, 21, 28, 34, 36 and 40. The salinity of the two beaches where the strains were isolated ranges from 20 to 36 (RÖRIG; GARCIA, 2003). The extreme values 15 and 40 were used to test the species response to values beyond its supposed range of salinity tolerance. In each experimental flask, we inoculated $5 \mathrm{~mL}$ of exponential phase culture. Other culture conditions followed the standard conditions described above.

Cellular quantification was made right after the inoculation $\left(\mathrm{t}_{0}\right)$, and after $2,3,4,5$, and 6 days. The $3 \mathrm{~mL}$ aliquots were fixated with $4 \%$ lugol and quantified in $1 \mathrm{~mL}$ Sedgewick-Rafter chambers under microscopy, with 100X magnification. The growth curves generated were plotted and the exponential phase was visually determined.

Growth rates were calculated from exponential phases data according to equation 1 and cellular doubling time according to equation 2 (COOMBS; HALL, 1982).

$$
\mu=\left(\ln \mathrm{N}_{\mathrm{f}}-\ln \mathrm{N}_{0}\right) / \mathrm{T}_{\mathrm{f}} \text { equation } 1
$$

Where: $\mu$ is the exponential growth rate $\left(\right.$ day $\left.^{-1}\right) ; N_{0}$ is the initial cell density (cell. $\mathrm{mL}^{-1}$ ); $\mathrm{N}_{\mathrm{f}}$ is the final cell density (cell.mL $\mathrm{m}^{-1}$ ); $\mathrm{T}_{\mathrm{f}}$ is the time interval between $\mathrm{N}_{0}$ and $\mathrm{N}_{\mathrm{f}}$.

$\mathrm{G}=\ln 2 / \mu$ equation 2

Where: $\mathrm{G}$ is the cellular doubling time; $\ln 2$ is the natural logarithm of $2 ; \mu$ is the daily exponential growth rate $\left(\right.$ day $\left.^{-1}\right)$.

The growth rates were compared through variance analysis (ANOVA; Bonferroni test) to verify if they were significantly different.

\section{BIOMASS AND EXSUDATE PRODUCTION FOR ANALY-}

\section{SIS AND BIOASSAYS}

Two biomass types were used for biochemical analysis and for exsudate and extract production: (a) concentrated biomass from the strain cultures; and (b) concentrated biomass from the plankton net bloom sampling. For the first case, the strains were cultured in 9 L Carboy flasks with aeration. After 15 days of culturing, the biomass was centrifuged and separated from the supernatant (exsudate). The exsudates were frozen, and the biomass, lyophilized for posterior use in assays and analysis. For biomass obtained from the algal blooms, the procedure was similar, with centrifugation and subsequent separation of the biomass fractions and exudates.

LUMINESCENT BACTERIA TEST WITH A. GLACIALIS EXSUDATES

The exudates produced by the two strains and the one obtained from Rincão beach field sample were used as samples in the Vibrio fischeri bacteria luminescence inhibition assay (Lumistox (C). In this assay, the greater the inhibition of the light emission, relative to a control, the greater the toxicity of the sample (ISO 11348-1, 1998). The Lumistox test was performed in triplicate at different concentrations of exudates.

The test was conducted with various exsudate dilutions, as shown in Table 1, as well as controls, consisted of pure culture medium. The exposure temperature was $15^{\circ} \mathrm{C}$. The inoculum was the bacterial main culture, which was added to the samples (exsudates). After samples and control acclimation, $500 \mathrm{uL}$ of standard culture was inoculated in each experimental flask. Luminescence of each flask at initial time and after 30 min exposure was determined using a luminometer Lumistox 300 Hach-Lange.

Table 1. Features of Vibrio fischeri bacteria luminescence inhibition assay (Lumistox (C) performed with cultures and field samples exsudates.

\begin{tabular}{|c|c|c|c|}
\hline Sample & $\begin{array}{l}\text { Exsudate } \\
\text { origin }\end{array}$ & Dilutions & Temperature \\
\hline NAV strain & $\begin{array}{l}\mathrm{F} / 2 \text { medium } \\
\text { culture }\end{array}$ & $\begin{array}{l}3 \%, 6 \%, \\
12 \%, 25 \%, \\
50 \%\end{array}$ & $15^{\circ} \mathrm{C}$ \\
\hline RIN strain & $\begin{array}{l}\text { F/2 medium } \\
\text { culture } \\
\text { IMR medium } \\
\text { culture }\end{array}$ & $50 \%, 80 \%$ & $15^{\circ} \mathrm{C}$ \\
\hline $\begin{array}{l}\text { Bloom Rincão } \\
\text { beach }\end{array}$ & Field sample & $50 \%, 80 \%$ & $15^{\circ} \mathrm{C}$ \\
\hline
\end{tabular}

Algal growth inhibition test with A. glacialis exsudates 
The growth inhibition test with the microalgae Phaeodactylum tricornutum (ISO 10253, 1995) was applied to check the possible allelopathic effect of $A$. glacialis exsudates. This assay was carried out only with exsudates from RIN strain, grown in IMR and F/2 media. Five exsudate dilutions were used in triplicate: $0 \%$ (control, consisting of pure culture medium); $10 \% ; 25 \% ; 50 \%$; and $100 \%$, with salinity adjusted to 30 . The test was conducted in static bench with $24 \mathrm{~h}$ photoperiod with standard irradiance and temperature (see above). In each flask $5 \mathrm{ml}$ of $P$. tricornutum culture growing in exponential phase was inoculated. Aliquots of $3 \mathrm{ml}$ were taken from all flasks for cell quantification right after inoculation $\left(\mathrm{t}_{0}\right)$ and after $72 \mathrm{~h}$ and $96 \mathrm{~h}$. These aliquots were preserved with $4 \%$ lugol and subsequently quantified in $1 \mathrm{~mL}$ Sedgewick-Rafter chambers under microscope, with 100X magnification.

\section{ANTIMICROBIAL ACTIVITY OF A. GLACIALIS $E X$ - TRACTS}

The biomass collected from Rincão patches in $13 / 07 / 2013$ was used to evaluate the possible antimicrobial activities. In the procedure, $10 \mathrm{~g}$ of freeze-dried biomass were initially washed with ammonium formate $(0.5$ $\mathrm{M})$ at a ratio of two parts of reagent to one part of biomass $(2: 1)$, in order to remove salt. Formate was allowed to act for $5 \mathrm{~min}$, then the sample was centrifuged for other 5 min at 4,000 rpm. The supernatant was removed and the sedimented biomass was again resuspended with formate (2:1), repeating this process three more times. The desalted biomass was exhaustively extracted with $92 \%$ ethanol. The resulting extract was concentrated under pressure resulting in an aqueous fraction, a hexane fraction and a butane fraction. All fractions were tested for antifungal and antibacterial activities. The antimicrobial activity was evaluated by the disk diffusion test (OLIVEIRA et al., $2005)$ with some modifications. The filter paper discs (6 $\mathrm{mm}$ ) were impregnated with $20 \mu \mathrm{L}$ of extract solutions and then placed on Muller-Hinton agar plates (HIMEDIA), which were inoculated with the microorganism to be tested according to the standard protocol described by CLSI / NCCLS (2002). The plates were incubated at 35 $\pm 1{ }^{\circ} \mathrm{C}$, and after $18 \mathrm{~h}$ the diameter of the inhibition zone were measured. Paper discs containing only the solvents were used as negative control. The tested organisms were: Sporogenes perfringens (ATCC 11437), Staphylococcus aureus (ATCC 25923), Staphylococcus epidermidis (ATCC 12228), Enterococcus faecalis (ATCC 29212),
Streptococcus pneumonie (ATCC 49619), Streptococcus pyogenes (ATCC 19615), Enterobacter cloacae (ATCC 13047), Escherichia coli (ATCC 25922), Enteroccocus faecalis (ATCC 29212), Klebsiella pneumonie (ATCC 13883), Salmonella typhimurium (ATCC 14028), Shigella flexneri (ATCC 12022), Pseudomonas aeruginosa (ATCC 27853), Candida albicans (ATCC 10231) e C. tropicalis (ATCC 13803).

\section{LIPID CONTENT AND FATTY ACID PROFILE}

Total lipids were extracted and quantified by the method of BLIGH; DYER (1959). Aliquots of $0.2 \mathrm{~g}$ of freezedried biomass were transferred to test tubes covered with aluminum foil, in which $1.5 \mathrm{~mL}$ of chloroform:methanol $(1: 2 \mathrm{v} / \mathrm{v})$ was added. Each tube was shaken for $5 \mathrm{~min}$ in vortex. Then, $0.4 \mathrm{~mL}$ of distilled water was added and the tube was vortexed for $2 \mathrm{~min}$ more. Further, $0.5 \mathrm{~mL}$ of chloroform was added and again vortexed for $2 \mathrm{~min}$. Finally, another $0.5 \mathrm{~mL}$ of distilled water was added followed by vortexing for more $2 \mathrm{~min}$. After this process, the tubes were centrifuged for $5 \mathrm{~min}$ at $3,000 \mathrm{rpm}$ to phase separation. For full extraction of lipids samples remained for $24 \mathrm{~h}$ at $4^{\circ} \mathrm{C}$ in dark. The lipid extract was recovered with Pasteur pipette and separated into another tube with known mass. To the residual biomass in the tubes, $2 \mathrm{~mL}$ chloroform were added, then vortexed and centrifuged recovering the whole lipid phase to the first tube. The chloroform was then evaporated and the tubes with total lipids sample were weighed discounting the weight of the tube to find the amount of lipids in each sample.

With the obtained extracts it was also performed a qualitative and quantitative analysis of fatty acids by gas chromatography. The lipid fraction was esterified to obtain the fatty acids methyl esters, according to the methodology proposed by PALAU et al., (2007). The fatty acid analysis was performed on a Varian gas chromatograph model - 3400CX equipped with a flame ionization detector and a fused silica column of $30 \mathrm{~m}$ length and $0.32 \mathrm{~mm}$ in diameter, containing polyethylene glycol as stationary phase. The carrier gas was nitrogen at $0.5 \mathrm{~mL}$.min-1. Temperatures of the injector and detector were $250^{\circ} \mathrm{C}$ and $280^{\circ} \mathrm{C}$, respectively. The initial column temperature was $100^{\circ} \mathrm{C}$ then increased at $8^{\circ} \mathrm{C} \cdot \mathrm{min}^{-1}$ until $230^{\circ} \mathrm{C}$, staying at this temperature for $20 \mathrm{~min}$. The fatty acids were identified by comparison of retention times with standard (Sigma Supelco; Bellefonte, USA) and quantified by area normalization. 


\section{RESULTS}

The two strains showed satisfactory growth in standard laboratory conditions and in the different tested conditions (agitation, salinity). In general, both strains grew better in agitated condition. Differences were significant between agitated and static conditions for NAV strain in F/2 culture medium, and RIN strain in IMR culture medium, but not significant for RIN strain in F/ 2 culture medium. However even in the latter case the agitated condition resulted in higher growth rate (Table 2). The general growth pattern was similar between the two strains, but the results were limited because there was no result for NAV strain in IMR medium. In this experiment, the exponential growth phase was expressed from the beginning of the experiment $\left(\mathrm{T}_{0}\right)$ until 48 hours of growth. It is important to emphasize that the strains were acclimated to experimental conditions for 48 hours before the $\mathrm{T}_{0}$.

In addition to the influence on the growth rate, agitation was shown to affect cell and chain morphology. Strains of $A$. glacialis grow well in culture, but after a few weeks, aberrations began to appear in the cells, such as reduction of the spine and decreased overall cell size, besides the non-formation of the typical helicoidal chains, observed in samples from the natural environment. However, in cultures with agitation, the normal cell and chain morphology persisted longer, features not observed in cultures without agitation, especially after 7 days of growth. These characteristics were confirmed in parallel cultures, conducted to verify these changes. Finally, despite the lower growth rates observed in IMR medium, there was less cell and chain aberrations than those in $\mathrm{F} / 2$ medium.

Table 2. Results of the growth experiment with the two Asterionellopsis glacialis sensu lato strains under different culture media, with and without agitation. NAV: Navegantes strain; RIN: Rincão strain; $\mathrm{N}_{0}$ : initial cell density $\left(\right.$ cell. $\left.\mathrm{mL}^{-1}\right)$; $\mathrm{N}_{\mathrm{f}}$ : final cell density (cell. $\mathrm{mL}^{-1}$ ); $\mathrm{T}$ : growth time between $\mathrm{T}_{0}$ e $\mathrm{T}_{\mathrm{f}} ; \mu$ : growth rate (day ${ }^{-1}$ ); $\mathrm{G}$ : duplication time (days). The values for $\mathrm{N}_{0}, \mathrm{~N}_{\mathrm{f}}, \mu$ e $\mathrm{G}$ are mean of 4 replicates. Different letters beside growth rate values indicate significant differences and equal letters indicate absence of significant differences $(\mathrm{p}<0.05)$.

\begin{tabular}{|c|c|c|c|c|c|c|c|}
\hline Strain & Culture media & Agitation & $\underset{\left(\text { cell.mL } \mathbf{L}^{-1}\right)}{\mathbf{N}_{0}}$ & $\underset{\text { (cell.mL }}{\mathbf{N}_{\mathbf{f}}}$ & $\underset{\text { (days) }}{\mathbf{T}}$ & $\begin{array}{c}\boldsymbol{\mu} \\
\left(\text { day }^{-1}\right)\end{array}$ & $\begin{array}{c}\text { G } \\
\text { (days) }\end{array}$ \\
\hline \multirow{2}{*}{ NAV } & \multirow{2}{*}{$\mathrm{F} / 2$} & Static & 49250 & 155750 & 2 & $0.57^{\mathrm{a}}$ & 1.20 \\
\hline & & Agitated & 63000 & 262000 & 2 & $0.82^{\mathrm{b}}$ & 0.84 \\
\hline \multirow{4}{*}{ RIN } & \multirow{2}{*}{$\mathrm{F} / 2$} & Static & 40333 & 222250 & 2 & $0.85^{\mathrm{b}}$ & 0.81 \\
\hline & & Agitated & 34025 & 218250 & 2 & $0.93^{\mathrm{b}}$ & 0.74 \\
\hline & \multirow{2}{*}{ IMR } & Static & 113000 & 446750 & 2 & $0.69^{\mathrm{a}}$ & 1.01 \\
\hline & & Agitated & 114750 & 670750 & 2 & $0.88^{\mathrm{b}}$ & 0.78 \\
\hline
\end{tabular}

Comparing the growth of the two strains in different salinities with $\mathrm{F} / 2$ medium, the results indicated that $A$. glacialis s.1. shows satisfactory growth in a considerable range of salinities $(15$ - 40) and can survive these variations. However, there was a trend of greater growth between salinities 21 and 28 in both strains, with apparent preference of NAV strain for salinity 21 and RIN strain for salinity 28. In this experiment NAV strain showed higher rates than in the experiment with variation of culture media and agitation. It is noteworthy that the time considered for the exponential phase in this experiment was 72 hours, and the strains were acclimated to test conditions in different salinities for 96 hours before $\mathrm{T}_{0}$.
Comparing the growth of the two strains in different salinities with F/2 medium, the results indicated that A. glacialis s.l. shows satisfactory growth in a considerable range of salinities $(15$ - 40) and can survive these variations. However, there was a trend of greater growth between salinities 21 and 28 in both strains, with apparent preference of NAV strain for salinity 21 and RIN strain for salinity 28. In this experiment NAV strain showed higher rates than in the experiment with variation of culture media and agitation. It is noteworthy that the time considered for the exponential phase in this experiment was 72 hours, and the strains were acclimated to test conditions in different salinities for 96 hours before T0 (Table 3). 
Table 3. Results of the growth experiment with the two Asterionellopsis glacialis sensu lato strains under diferente salinities. NAV: Navegantes strain; RIN: Rincão strain; $\mathrm{N}_{0}$ : initial cell density (cell. $\left.\mathrm{mL}^{-1}\right)$; $\mathrm{N}_{\mathrm{f}}$ : final cell density (cell.mL $\mathrm{m}^{-1}$ ); $\mathrm{T}$ : growth time between $\mathrm{T}_{0}$ e $\mathrm{T}_{\mathrm{f}} ; \mu$ : growth rate $\left(\right.$ day $\left.^{-1}\right)$; $\mathrm{G}$ : duplication time (days). The values for $\mathrm{N}_{0}, \mathrm{~N}_{\mathrm{f}}, \mu$ e $\mathrm{G}$ are mean of 3 replicates. Different letters in the side of growth rate values indicate significant differences and equal letters indicate absence of significant differences $(\mathrm{p}<0.05)$.

\begin{tabular}{|c|c|c|c|c|c|c|}
\hline Strain & Salinity & $\begin{array}{c}\text { No } \\
\text { (cell.mL-1) }\end{array}$ & $\begin{array}{c}\mathrm{Nf} \\
\text { (cell.mL-1) }\end{array}$ & $\begin{array}{c}T \\
\text { (days) }\end{array}$ & $\underset{(\text { day-1) }}{\mu}$ & $\begin{array}{c}G \\
\text { (days) }\end{array}$ \\
\hline NAV & 15 & 12500 & 41890 & 3 & $0.40 \mathrm{a}$ & 1.72 \\
\hline NAV & 21 & 15520 & 354220 & 3 & $1.04 \mathrm{~b}$ & 0.66 \\
\hline NAV & 28 & 14680 & 190230 & 3 & $0.85 b$ & 0.81 \\
\hline NAV & 34 & 12460 & 68780 & 3 & $0.57 \mathrm{c}$ & 1.22 \\
\hline NAV & 36 & 22140 & 101420 & 3 & $0.51 \mathrm{c}$ & 1.37 \\
\hline NAV & 40 & 17540 & 87520 & 3 & $0.54 \mathrm{c}$ & 1.29 \\
\hline RIN & 15 & 21360 & 75250 & 3 & $0.42 \mathrm{a}$ & 1.65 \\
\hline RIN & 21 & 20540 & 170500 & 3 & $0.71 b c$ & 0.98 \\
\hline RIN & 28 & 19550 & 285690 & 3 & $0.89 \mathrm{~b}$ & 0.77 \\
\hline RIN & 34 & 22140 & 138450 & 3 & $0.61 \mathrm{c}$ & 1.13 \\
\hline RIN & 36 & 22510 & 115230 & 3 & $0.54 \mathrm{c}$ & 1.27 \\
\hline RIN & 40 & 23220 & 98560 & 3 & $0.48 \mathrm{ac}$ & 1.44 \\
\hline
\end{tabular}

The Vibrio fischeri luminescence inhibition assay (Lumistox (C) performed with exudates showed no significant toxicity (Table 4). In fact, there was negative inhibition, that is, stimulation of $V$. fischeri luminescence in most dilutions. At least in the RIN strain sample with IMR medium NAV strain with F/2 medium, the higher the concentration, the greater the stimulatory activity. The only negative effect on the luminescence occurred with the exudate obtained from the field sample of Rincão beach at $80 \%$, possibly indicating some distinguishing feature of exudates when in natural condition. All inhibition data generated were statistically significant $(\mathrm{p}<0.05)$.

Table 4. Results of the Vibrio fischeri luminescence inhibition assay (Lumistox (C) with Asterionellopsis glacialis s.l. exsudate samples. NAV: Navegantes strain; RIN: Rincão strain.

\begin{tabular}{lcc}
\hline Exsudate sample & $\begin{array}{c}\text { Dilution } \\
(\mathbf{\%})\end{array}$ & $\begin{array}{c}\text { Luminescen- } \\
\text { ce Inhibition } \\
\mathbf{( \% )}\end{array}$ \\
\hline Field sample - Rincão Beach & 50 & -1.33 \\
Strain RIN - F/2 medium & 80 & 4.55 \\
& 50 & -7.90 \\
& 80 & -4.59
\end{tabular}

\begin{tabular}{lcc}
\hline Exsudate sample & $\begin{array}{c}\text { Dilution } \\
(\mathbf{\%})\end{array}$ & $\begin{array}{c}\text { Luminescen- } \\
\text { ce Inhibition } \\
\mathbf{( \% )}\end{array}$ \\
\hline Strain RIN - IMR medium & 50 & -8.96 \\
& 80 & -10.69 \\
Strain NAV - F/2 medium & 6 & -57.31 \\
& 12 & -90.24 \\
& 25 & -110.28 \\
& 50 & -226.38 \\
\hline
\end{tabular}

In addition, extracts made with environment dry biomass showed no inhibitory effects on any of the $15 \mathrm{mi}-$ croorganisms tested, indicating absence of antimicrobial activity.

The algal growth inhibition test with $P$. tricornutum, performed only with exudates from RIN strain, showed a possible allelopathic effect, with decreased growth rate in treatments with exsudate (Table 5). The effect was slightly more evident in the strain grown in IMR medium. In the experiment carried out with the strain grown in F/2 medium, there was not a clear correspondence in terms of decreased growth rates with increasing concentration of the exudate (Table 5). 
Table 5. Results of the algal growth inhibition test with Phaeodactylum tricornutum performed with exsudates of Asterionellopsis glacialis s.l.

\begin{tabular}{ccc}
\hline \multirow{2}{*}{ Exsudate concentration (\%) } & \multicolumn{2}{c}{$\boldsymbol{\mu}$ of Phaeodactylum tricornutum $\left(\right.$ day $\left.^{-1}\right)$} \\
\cline { 2 - 3 } & Strain RIN - IMR Medium & \multicolumn{1}{c}{ Strain RIN - F/2 Medium } \\
\hline 0 & 1.11 & 1.02 \\
10 & 0.95 & 0.52 \\
25 & 0.94 & 0.88 \\
50 & 0.78 & 0.87 \\
100 & 0.68 & 0.79 \\
\hline
\end{tabular}

\section{LIPID CONTENT AND FATTY ACID PROFILE}

The biomass of the two strains generated in cultures under different conditions showed similar values and relatively low lipid content (average $=11.3 \%$ ). The highest value was obtained for RIN strain in IMR medium and the lowest for NAV strain in F/2, however, in the latter case, the lipid extraction was performed with biomass grown for 7 days, while in others, growth was extended for 15 days (Table 6). This growth time difference certainly influence the algae metabolism, then the comparison between them cannot be fully validated.

Regarding the fatty acid profile the differences were very evident between RIN and NAV strains, but again, the cultivation time may have acted as an additional factor of influence (Table 6). Between the two treatments of RIN strain (F/2 medium and IMR medium), grown for 15 days, the differences in fatty acid profile were small. In both, the saturated fatty acids myristic (14:0), pentadecanoic (C15:0), palmitic (C16:0) and stearic (C18:0) and the unsaturated fatty acids Oleic (C18:1 $\omega-9)$, linoleic (C18:

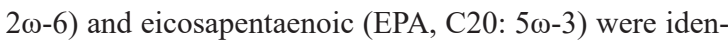
tified. But the profile obtained for NAV strain grown with F/2 medium for 7 days, proved to be quite different from the others. In this, only saturated fatty acids myristic and palmitic and unsaturated palmitoleic, arachidonic and EPA were detected. Arachidonic acid was unique to NAV strain and pentadecanoic was only detected in RIN strain. In RIN strain, the major fatty acid was myristic, while in NAV strain was palmitoleic. However, the main difference was the percentage of EPA in NAV strain, which was about 10 times higher than that obtained from RIN strain.
Table 6. Lipid content and fatty acid profile in biomass of two strains of Asterionellopsis glacialis s.l. grown under different coditions. RIN: Rincão strain; NAV: Navegantes strain. F/2 and IMR are culture media names.

\begin{tabular}{|c|c|c|c|}
\hline \multirow[b]{2}{*}{ Fatty acids } & \multicolumn{3}{|c|}{ Strains and culturing time } \\
\hline & $\begin{array}{c}\text { RIN - } \\
\text { IMR } \\
15 \text { days } \\
(\%)\end{array}$ & $\begin{array}{c}\text { RIN - } \\
\text { F/2 } \\
15 \text { days } \\
(\%)\end{array}$ & $\begin{array}{c}\text { NAV - } \\
\text { F/2 } \\
7 \text { days } \\
(\%)\end{array}$ \\
\hline Miristic (C14:0) & 34.2 & 40.8 & 20.2 \\
\hline Pentadecanoic(C15:0) & 2.6 & 2.4 & - \\
\hline Palmitic (C16:0) & 23.1 & 15.0 & 9.3 \\
\hline Palmitoleic (C16:1) & 34.9 & 32.2 & 32.2 \\
\hline Estearic (C18:0) & 0.8 & 1.20 & - \\
\hline Oleic $(\mathrm{C} 18: 1 \omega-9)$ & 1.6 & 2.8 & - \\
\hline Linoleic $(\mathrm{C} 18: 2 \omega-6)$ & 1.3 & 2.0 & - \\
\hline 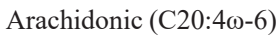 & - & - & 4.5 \\
\hline EPA $(C 20: 5 \omega-3)$ & 1.4 & 3.6 & 32.1 \\
\hline TOTAL LIPIDS & 13.7 & 11.2 & 9.0 \\
\hline
\end{tabular}

\section{DISCUSSION}

\section{GROWTH OF A. GLACIALIS S.L. IN CULTURE}

The growth of $A$. glacialis s.l. in laboratory conditions, based on the results obtained for the two strains studied, proved to be satisfactory, especially under agitation. However, the cultures were not durable, since after a few weeks cells exhibited morphological changes and mortality in the flasks. The duration and health of the cultures were higher in treatments under agitation and culture medium with higher proportion of phosphorus and silica (IMR). Possibly the largest amount of silica in IMR medium has been important to prevent frustule degeneration. Similar situations with aberrations leading to cultures viability loss have been described for other cultivated species, being partially attenuated under silica supersaturation 
conditions (VRIELING, 1999; SAFONOVA et al., 2007). The presence of heavy metals can also affect the silica polymerization process (RIJSTENBIL et al., 1994), but this condition was not assessed in this study. Another possibility may be the low solubility of the silicon salt used in the culture media. An indication of this problem was sometimes seen after media sterilization using heat (autoclaving), when increased turbidity could be an indication of salt precipitation. Finally, it is possible that the different condition of laboratory cultures, with a lower diversity of bacteria and cofactors than in the natural environment, was also crucial for morphological degeneration of $A$. glacialis in culture. WINDLER et al. (2014) found that the bacteria present in natural marine environment may have a fundamental influence on the stability of long-term cultures of diatoms, since they verified that aberrations and loss of viability in diatoms were most common and severe in axenic cultures.

One of the diatoms reactions to environmental stress is the induction of sexual reproduction with auxospore formation. Although there is no evidence in the literature about auxospore formation in A. glacialis, in some cultures performed during this study cells were observed with a reduction in the typical spine, and cell tumescence, approaching a spherical shape, which can be an indication of auxospore formation. However, this issue needs to be evaluated in specific experiments.

Not all species of diatoms exhibit this behavior in culture. $P$. tricornutum, for example, is grown continuously for years without showing loss of viability. Interestingly, this species has very lightly silicified frustules or also can grow without forming frustules.

The formation of the typical helicoidal chains was noted in treatments with agitation. Also, cultures with a certain degree of morphological degeneration recovered normal morphology once submitted to agitation. Turbulence is an important environmental variable for all diatoms, however, for surf diatoms this condition is critical, given the extreme turbulence of the surf zones and the role that it plays in the surf diatoms life cycle.

In general, RIN strain grew better than NAV strain in the tested conditions. However, the experiments were performed at different moments, and so, other variables could have influenced these differences. In other words, considering culture growth, at least in standard conditions of salinity, the strains are very similar.

When evaluating the strains growth under different salinities, an acclimation to a wide range of salinities (15
- 40) was observed. This condition is certainly involved in the success of this species in the complex and variable surf zone environment. In these shallow environments, salinity can vary quickly because of rainfall events, freshwater flow through underground aquifers, river inflow and water leakage coming from wetlands from behind the dunes (CAMPBELL; BATE, 1997). Despite surviving in all these salinities, both strains showed a preference for salinities 21 and 28, which are the average salinity found in the studied environments (RÖRIG et al., 1997). NAV strain showed slight preference for salinity 21 , while RIN strain for salinity 28. Interestingly, Navegantes beach is smaller and strongly influenced by a big river in one of its ends (Itajaí-açu river), presenting generally lower salinities. Rincão beach, in turn, is situated on an extensive sandy coastline and farther away from large rivers. So, these small differences in salinity preferences may not be random, but related to adaptive history, suggesting that the strains are different ecotypes or even different species. The possible confirmation of these differences may indicate that the genomic diversity discovered by KACZMARSKA et al. (2014), which suggested the occurrence of cryptic species within what was once considered a single species, has reflection in the ecophysiological profile.

BIOLOGICAL ACTIVITIES OF EXSUDATES AND EXTRACTS OF A. GLACIALIS S.L.

Since the first studies on biological activities related to A. glacialis s.l. (ABREU et al., 2003; AUBERT; et al., 1970; RIQUELME; ISHIDA, 1988; SHIMIZU, 1993) little has been done at experimental level to prove or explain these properties. The papers above cited stimulated the experimental initiatives in the present study, especially the study of ABREU et al., (2003), which pointed a decoupling between dissolved primary production of A. glacialis and total bacteria in the natural environment (Cassino beach, lat. $32^{\circ} 13^{\prime} \mathrm{S}$, long. $52^{\circ} 15^{\prime} \mathrm{W}$, Southern Brazil). We expected to detect antimicrobial activity in exudates and/or extracts and eventually allelopathic activity, which would help explain the adaptative success of the species in the beach environments where it occurs. However, the implemented approaches have failed to demonstrate such biological activities. On the contrary, a very sensitive bacteria used in ecotoxicological tests (Vibrio fischeri) was stimulated by the presence of $A$. glacialis s.l. exudates. This finding can be explained by the presence of nutrients useful for bacteria in these exudates. Moreover, the 
detection of mild toxicity in the sample from the natural environment may indicate that the physiology and metabolome of the algae change under different conditions. Perhaps the presence of bacteria and other competitors or grazers in the natural environment stimulates the production of defense metabolites in algae, a fact that has been found in some studies (POHNERT et al., 2007). The smaller bacterial diversity in laboratory cultures may not represent stimulus for this metabolite production. Additionally, physico-chemical conditions can exert this stimulus or activate expression of genes linked to secondary metabolism - a subject that must be evaluated in further studies. Finally, considering the new A. glacialis taxonomic situation, perhaps the species found in Cassino beach is metabolically different and present a more active chemical arsenal, but that is just speculation.

The fact that even the biomass extracts have not shown antimicrobial activity suggests that there was no production of metabolites with such properties, since eventually the algae could be producing but not excreting as exudate.

Moreover, the allelopathic activity against $P$. tricornutum, despite not being very strong, indicates the possible presence of metabolites which hinder the growth of other algae. To prove this activity it would be recommended to run the test with other more sensitive species, since $P$. tricornutum is known to have allelopathic activity (SHARP et al., 1979), as well as having very robust growth in laboratory cultures. The chemical nature of the possible allelopathic agents is very different from species to species and remain poorly understood (SOLÉ et al., 2005). However, recent studies have shown that this is a promising research field in algal biotechnology, where the correct application of allelopathic substances can promote the success of the species of interest (MENDES; VERMELHO, 2013).

The results obtained in this study, however, cannot be considered definitive, since other experiments and condition variations must be programmed to make more reliable conclusions. However, it shows that the biological activity of A. glacialis s.l. is not obvious and no practical applications of the species can be glimpsed in this sense at the time. So, its success in the surf zones seems to be more related to physiological adaptation to this dynamic environment and its rapid growth, than chemically mediated processes linked to secondary metabolism.
OIL CONTENT AND LIPID PROFILE OF A. GLACIALIS S.L.

The lipid content in microalgae can vary from 1 to $40 \%$ of dry mass, and under special growth conditions, can reach up to $85 \%$ (BECKER, 2004). Some diatoms are already known to produce high levels of fatty acids, especially polyunsaturated omega-3 and omega- 6 . Well known examples are $P$. tricornutum, Thalassiosira spp. and Odontella aurita (YONGMANITCHAI; WARD, 1991). Saturated and polyunsaturated fatty acids (PUFA), have been found in A. glacialis by VISO; MARTY (1993), but in smaller amounts than the found in the present work for NAV strain. Interestingly, RIN strain showed lower levels of EPA, similar to those described by these authors.

The cultivation time may influence the amount and profile of produced fatty acids. RIN strain was processed to obtain oil for fatty acids analysis during stationary phase culture (15 days), while for NAV strain the processing was performed near exponential phase (7 days). These different cultivation times can explain, at least in part, the variability in results. In cultures of P. tricornutum, YANG et al. (2013) showed that the species accumulated 20.3\% EPA in the exponential phase and $11.7 \%$ in stationary phase. This result is in agreement with that obtained in the present study for NAV, when EPA was produced in greater quantities in shorter culture times (exponential phase). The causes of this change refer to structural function of this fatty acid in the cell, related to the stability and fluidity of the membrane during photosynthesis, which is more intense in the exponential phase (VALENTINE; VALENTINE, 2004).

The variation in the lipid content can also be associated with the genomic differences. Accordingly, the results of genomic diversity in A. glacialis obtained by KACZMARSKA et al. (2014) could be part of the explanation for the fatty acid profiles variation between the strains. Probably, the strains have different metabolism by genetic reasons and then produce different levels and types of lipids/fatty acids.

Although the lipid levels were not very high for the strains of A. glacialis studied here, the large biomass of this species in the beaches where it occurs, suggests that it is the main source of fatty acids for beach fauna. In this case, the presence of EPA in their biomass represents an increase in nutritional quality for beach fauna, showing that A. glacialis is trophically important not only in quantitative but also qualitative terms. Analyzing the fatty acid profile of two important components of the fauna from 
beaches where patches of $A$. glacialis occur - mullets and white mussels - it can be seen some congruence between the composition observed in A. glacialis and these two animals (Table 7). Draws attention the similarity in contents of some fatty acids like arachidonic, palmitic and EPA.

MENEZES et al. (2008) found 15 different fatty acids in mullet (Mugil cephalus) being the main ones: Oleic $(6.27 \%)$, linoleic $(6.28 \%)$, alpha-linolenic (5.61\%), eicosapentaenoic - EPA (5.42\%) and docosahexaenoic acid - DHA (5.05\%). Another study found the presence of saturated and polyunsaturated fatty acids in mullets being $23.5 \%$ of these from omega-3 class (LEMKE et al., 2011). The studies above reinforce the idea that $A$. glacialis is an important source of EPA, since A. glacialis seems to be one of the main food item in stomach contents of mullet species (GARCIA; GIANUCA, 1997).

Table 7. Comparison of fatty acid profiles among Asterionellospsis glacialis sensu lato (average quantities among different strains and culture conditions) and two important members of the beach fauna that eat on A. glacialis. Only fatty acids that are commom in the three species were reported. Mugil are from MENEZES et al. (2008) and white mussel are from DE MORENO, et al. 1976).

\begin{tabular}{|c|c|c|c|}
\hline Fatty Acid & $\begin{array}{c}\text { Average in } A . \text { glacialis } \\
\text { strains }\end{array}$ & $\begin{array}{c}\text { Mullet } \\
\text { (Mugil cephalus) }\end{array}$ & $\begin{array}{c}\text { White mussel } \\
\text { (Mesodesma mactroides) }\end{array}$ \\
\hline Miristic (C14:0) & 31.6 & 7.66 & 6.57 \\
\hline Pentadecanoic (C15:0) & 1.68 & 9.14 & 3.4 \\
\hline Palmitic (C16:0) & 15.8 & 12.97 & 20.57 \\
\hline Palmitoleic (C16:1) & 33.11 & - & - \\
\hline Estearic $(\mathrm{C} 18: 0)$ & 0.66 & 4.26 & 6.07 \\
\hline Oleic $(\mathrm{C} 18: 1 \omega-9)$ & 1.48 & 6.27 & 10.87 \\
\hline Linoleic $(\mathrm{C} 18: 2 \omega-6)$ & 1.11 & 6.28 & 1.97 \\
\hline Arachidonic (C20:4 $\omega-6)$ & 1.5 & 2.97 & 1.17 \\
\hline $\mathrm{EPA}(\mathrm{C} 20: 5 \omega-3)$ & 12.36 & 5.42 & 13.07 \\
\hline DHA (C22:6 $\omega-3)$ & - & 5.05 & 8.6 \\
\hline
\end{tabular}

\section{CONCLUSION}

The results of this study contributed to better understand the ecophysiology, biochemistry and ecological importance of $A$. glacialis s.l. in sandy beaches where blooms or patches of this species occur. Bellow the main conclusions are listed:

Asterionellopsis glacialis is not so easy to cultivate, but possible. The main problem is that the strains, after weeks or months of laboratory culturing start to lose viability and present aberrations in the frustule, possibly related to the lack of some nutritional factor or to poor quality of culture media salts.

Among the several adaptations of this species to the surf zone environment it can be included the optimal growth at typical coastal salinities (20 to 30 ) and its tolerance to a wide range of salinities (15 to 40).

Antimicrobial activities previously suggested from field samples were not so evident in laboratory tests.
Maybe the in vitro conditions do not stimulate the algae to produce defense metabolites. Allelopathic effects were also not so evident. So, probably the success of this species to the surf zone environment is more related to physiological adaptations and chemical defenses are not so important, but more tests must be conducted to confirm this hypothesis.

The two strains of $A$. glacialis s.l. showed a variable fatty acid composition. Growth phase and genomic differences are among the possible explanations for this findings.

A. glacialis seems to be trophically important not only quantitatively, but also qualitatively, as source of high nutritional value fatty acids like EPA and oleic acid.

The ecophysiological and biochemical differences found among strains and field samples can be related to genomics or to a wide phenotypic variation induced by differences in growth or environmental conditions. 


\section{REFERENCES:}

ABREU, P.C.; RÖRIG, L.R.; GARCIA, V.M.T.; ODEBRECHT, C.; BIDDANDA, B. Decoupling between bacteria and the surf-zone diatom Asterionellopsis glacialis at Cassino Beach, Brazil. Aquat. Microb. Ecol. 32, p.219-228, 2003.

ANDERSEN, R. A. Algal culturing techniques. Elsevier: London, UK. 2006.

AUBERT, M.; PESANDO, D.; GAUTHIER, M. Phenomenes d'antibiosi d'origine phytoplanctonique en milieu marin. Rev. Int. Océanogr. Méd. 18(19), p. 69-76, 1970.

BECKER, W. Microalgae in human and animal nutrition. In: RICHMOND, A. (Ed). Handbook of microalgal culture: biotechnology and applied phycology. Blackwell Science: London, 2004. p. 312-351.

BEHRENS, P. W.; KYLE, D. J. Microalgae as a source of fatty acids. J. Food Lipids 3, p. 259-272, 1996.

BLIGH, E. G.; DYER, W. J. A rapid method of total lipid extraction and purification. Can. J. Biochem. Phys., 37(8), p. 911-917, 1959.

BRETT, M.T.; MÜLLER-NAVARRA, D.C. The role of highly unsaturated fatty acids in aquatic food web processes. Freshwater Biol. 38, p. 483-499, 1997.

BROWN, A.C. Food relationships on the intertidal sandy beaches of the Cape Peninsula. S. Afr. J. Sci. 60, p. 35-41, 1964.

BROWN, A.C.; MCLACHLAN, A. Ecology of Sandy Shores. Elsevier: Amsterdam. 1990. 328p.

CAMPBELL, E.E. The global distribution of surf diatom accumulations. Rev. Chil. Hist. Nat. 69, p. 495-501, 1996.

CAMPBELL, E.E.; BATE, G.C. Coastal features associated with diatom discoloration of surf-zones. Bot. Mar. 40, p. 179-185, 1997.

CLSI/NCCLS - National Committee for Clinical Laboratory Standards. Performance Standards for Antimicrobial Disk Susceptibility Tests-Approved Standard. Wayne: Pennsylvania, 2002.

COOMBS, J.; HALL, D.O. Techniques in bioproductivity and photosynthesis. Oxford: Pergamon Press. 1982.

DE MORENO, J.E.A.; MORENO, V.J.; BRENNER, R.R. Lipid Metabolism of the Yellow Clam, Mesodesma mactroides: I. Composition of the Lipids. Lipids 11, p. 334-340, 1976.

EPPLEY, R.W.; HOLMES, R.W.; STRICKLAND, J.D.H. Sinking rates of marine phytoplankton measured with a fluorometer. J. Exp. Mar. Biol. Ecol. 1(2), p. 191-208,1967.

GARCIA, V.M.T.; GIANUCA, N.M. The Beach and Surfzone. In: SEELIGER, U.; ODEBRECHT, C.; CASTELLO, J.P. (Eds.). Subtropical Convergence Environments: The Coast and Sea in the South Western Atlantic. Springer-Verlag: Heidelberg. 1997. p. 166-170.

GIANUCA, N. M. A preliminary account of the ecology of sandy beaches in southern Brazil. In: MCLACHLAN. A.; ERASMUS, T. (Eds.) Sandy beaches as ecosystems. Junk Publishers-The Hague: Gainesville. 1983. p. 413- 419.

GRIMA, M. E.; CAMACHO, F. G.; FERNÁNDEZ, A. F. G. Production of EPA from Phaeodactylum tricornutum. In: COHEN, Z. Chemical from microalgae. Taylor Francis: Boca Ratón. 1999. p. 57-87.

ISO 10253. Water quality - Marine algal growth inhibition test with Skeletonema costatum and Phaeodactylum tricornutum. 1995.
ISO 11348-1. Water quality - Determination of the inhibitory effect of water samples on the light emission of Vibrio fischeri (Luminescent bacteria test) - Part 1: Method using freshly prepared bacteria. 1998.

KACZMARSKA, I.; MATHER, L.; LUDDINGTON, I.A.; MUISE, F.; EHRMAN, J.M. Cryptic diversity in a cosmopolitan diatom known as Asterionellopsis glacialis (Fragilariaceae): Implications for ecology, biogeography, and taxonomy. Am. J. Bot. 101(2), p. 267-286, 2014.

LEMKE, S.; CASTRO, G.S.F.; FACCIN, G.L.; JORDÃO-JUNIOR, A.A.; VANNUCCHI, H.; TRAMONTE, V.L.C.G. Perfil de ácidos graxos de tainhas (Mugil Platanus) da região sul do Brasil. Nutrire 36, p. 344-344, 2011.

LERCARI, D.; BERGAMINO, L.; DEFEO, O. Trophic models in sandy beaches with contrasting morphodynamics: comparing ecosystem structure and biomass flow. Ecol. Model. 221(23), p. 2751-2759, 2010.

LEWIN, J.; SCHAEFER, C.T. The role of phytoplankton in surf ecosystems. In: MCLACHLAN. A.; ERASMUS, T. (Eds.) Sandy beaches as ecosystems. Junk Publishers-The Hague: Gainesville. 1983. p. 413- 419.

LEWIN, J.; MACKAS, D. Blooms of surf zone diatoms along the coast of the Olympic Peninsula, Washington. I. Physiological investigations of Chaetoceros armatum and Asterionella socialis in laboratory cultures. Mar. Biol. 16, p. 171-181, 1972.

MCLACHLAN, A.; LEWIN, J. Observations on surf phytoplankton blooms along the coast of South Africa. Bot. Mar. 24, p. 553-557, 1981.

MCLACHLAN, A.; ROMER, G. Trophic relationships in a high energy beach and surf-zone ecosystem. In: BARNES, M; GIBSON, R.N. (Eds.) Trophic Relationships in the Marine Environment. Aberdeen University Press: Aberdeen. 1990. pp. 356-371

MENEZES, M.E.S.; LIRA, G.M.; OMENA, C.M.B.; FREITAS, J.D.; SANT'ANA, A.E.G. Composição centesimal, colesterol e perfil de ácidos graxos dos peixes tainha (Mugil cephalus) $e$ camurim (Centropomus undecimalis) da Lagoa Mundaú, AL/ Brasil. Rev. Inst. Adolfo Lutz 67(2), 2008.

ODEBRECHT, C.; BERGESCH, M.; RÖRIG, L. R.; ABREU, P.C. Phytoplankton Interannual Variability at Cassino Beach, Southern Brazil (1992-2007), with Emphasis on the Surf Zone Diatom Asterionellopsis glacialis. Estuar. Coast. 33, p.570-583, 2010.

ODEBRECHT, C.; DUPREEZ, D.R.; ABREU, P.C.; CAMPBELL, E.E. Surf zone diatoms: A review of the drivers, patterns and role in sandy beaches food chains. Estuar. Coast. Shelf S. 150, p. 24-35, 2014.

OLIVEIRA, J.C.S. ; DIAS, I.J.M.; CÂMARA, C.A.G. Estudo comparativo do óleo essencial de Eugenia punivifolia (HBK) DC. de diferentes localidades de Pernambuco. Rev. Bras. Farmacog. 15(1), p.31-43. 2005.

PALAU, L.C.; RODRÍGUEZ, J.A.; LÓPEZ, M.O.A. Determinación de acidos grasos por cromatografía de gases - espectrofotometria de masas. In: VEGA, B. O. A.; VOLTOLINA, D. Métodos y herramientas analíticas en la evaluación de la biomasa microalgal. Centro de Investigaciones Biológicas del Noroeste: La Paz. 2007. p. 81-97.

POHNERT, G.; STEINKE, M.; TOLLRIAN, R. Chemical cues, defence metabolites and the shaping of pelagic interspecific interactions. Trends Ecol. Evol. 22, p. 198-204, 2007. 
RAPSON, A.M. Feeding and control toheroa (Amphidesma ventricosun Gray) (Eularnellibranchiata) populations in New Zealand. Aust. J. Mar. Fresh. Res. 5, p. 486-512, 1954.

RIJSTENBIL, J.W.; DERKSEN, J.W.M.; GERRINGA, L.J.A.; POORTVLIET, T.C.W.; SANDEE, A.; VAN DEN BERG, M.; VAN DRIE, J.; WIJNHOLDS, J.A. Oxidative stress induced by copper: defense and damage in the marine planktonic diatom Ditylum brightwellii, grown in continuous cultures with high and low zinc levels. Mar. Biol. 119, p. 583-590, 1994.

RIQUELME, C.E.; ISHIDA, Y. Chemotaxis of bacteria of extracellular producs of marine bloom algae. J. Gen. Appl. Microbiol. 34, p. 417-423, 1988.

RÖRIG, L. R.; RESGALLA, J.R.; PEZZUTO, P.R.; ALVES, E., MORELLI, F. Análise ecológica de um processo de acumulação da diatomácea Anaulus sp na zona de arrebentação da praia de Navegantes (Santa Catarina, Brasil). Oecol. Bras. 3, p. 29-43, 1997.

RÖRIG, L.R.; GARCIA, V.M.T. Accumulations of the surf-zone diatom Asterionellopsis glacialis (CASTRACANE) ROUND in Cassino Beach, Southern Brazil, and its relationship with environmental factors. J. Coastal Res. 35, p. 167-177, 2003.

SAFONOVA, T.A.; ANNENKOW, V.V.; CHEBYKIN, E.P.; DANILOVTSEVA, E.N.; LIKHOSHWAY, Y.V.; GRACHEV, M.A. Aberration of Morphogenesis of Siliceous Frustule Elements of the Diatom Synedra acus in the Presence of Germanic Acid. Biochemistry-Moscow 72(11), p. 1261-1269, 2007.

SHARP, J.H.; UNDERHILL, P.A.; HUGHES, D.J. Interaction (allelopathy) between marine diatoms: Thalassiosira pseudonana and Phaeodactylum tricornutum. J. Phycol. 15(4), p. 353-362, 1979.

SHIMIZU, Y. Microalgal metabolites. Chem. Rev., p. 1685-1698, 1993.

SOLÉ, J.; GARCÍA-LADONA, E.; RUARDIJ, P.; ESTRADA, M. Modelling allelopathy among marine algae. Ecol. Model. 183(4), p. 373-384, 2005)
SPOLAORE, P.; JOANNIS-CASSAN, C.; ISAMBERT, A.; DURAN, E. Commercial applications of microalgae. J. Biosci. Bioeng. 101(2), p. 87-96, 2006.

TALBOT, M.M.B.; BATE, G.C. Distribution patterns of the surf diatom Anaulus birostratus in an exposed surf zone. Estuar. Coast. Shelf S. 25, p. 137-153, 1988.

THAYER, L.A. Diatom water-blooms on the coast of Washington. Proc. La. Acad. Sci. p. 68-72, 1935.

VALENTINE, R.C.; VALENTINE, D.L. Omega-3 fatty acids in cellular membranes: a unified concept. Prog. Lipid Res. 43(5), p. 383-402, 2004.

VAN HEURCK, H. A treatise on the Diatomaceae. William Wesley \& Son: London. 1896. 230p.

VISO, A.; MARTY, J. Fatty acids from 28 marine microalgae. Phytochemistry 34(6), p. 1521-1993. 1993.

VRIELING, E.G. Silicon deposition in diatoms: Control by the pH inside the silicon deposition vesicle. J. Phycol. 35, p. 548$559,1999$.

WICHARD, T., POULET, S.A., HALSBAND-LENK, C., ALBAINA, A., HARRIS, R., LIU, D., POHNERT, G. Survey of the Chemical Defence Potential of Diatoms: Screening of Fifty Species for $\alpha, \beta, \gamma, \delta$-unsaturated aldehydes. J. Chem. Ecol. 31 (4), p. 949-958, 2005.

WINDLER, M.; BOVA, D.; KRYVENDA, A.; STRAILE, D.; GRUBER, A.; KROTH, P.G. Influence of bacteria on cell size development and morphology of cultivated diatoms. Phycol. Res. 62(4), p. 269-281, 2014.

YANG, Z.K.; NIU, Y.F.; MA, Y.H.; XUE, J.; ZHANG, M.H; YANG, W.D.; LIU, J.S.; LU, S.H. GUAN, Y.F. LI, H.Y. Molecular and cellular mechanisms of neutral lipid accumulation in diatom following nitrogen deprivation. Biotechnol. Biofuels 6(67), p. 1-67, 2013.

YONGMANITCHAI, W.; WARD, O.P. Growth of and ômega-3 fatty acid production by Phaeodactylum tricornutum under different culture conditions. Appl. Environ. Microb. 57, p. 419-425. 1991. 